\title{
Telaah Leksikal, Gramatikal, dan Kontekstual \\ Terhadap Makna Kata Syahida pada QS. al-Baqarah ayat 185
}

\author{
${ }^{1}$ Budi Kisworo, ${ }^{2}$ Hardivizon \\ Institut Agama Islam Negeri (IAIN) Curup \\ 1budikisworo55@gmail.com, ${ }^{2 h}$ hardi.vizon@gmail.com
}

DOI: $10.29240 /$ alquds.v4i1.1473

Submitted: 2019-04-06 | Revised: 2020-04-15 |Accepted: 2020-04-28

\begin{abstract}
This writing contains a semantic study of surah Al-Baqarah verse 185.As it is known, fasting is explained by Allah SWT through surah Al-Baqarah verse 183-185.In the verse 183, Allah explains the obligation of fasting for the believers; the verse 184 contains an explanation of the days in which the obligation of fasting must be fulfilled; and the verse 185 implies the way to know the coming of the month of Ramadan as a month in which fasting is obligated.The mufassirins understand the verse 185 of $\mathrm{Al}$ baqarah asinformation about the condition of someone who presents (meets) the month of Ramadan, then it is obligatory upon him to fast.This understanding departs from the word "shabida" which means "present" or "be" (in the country of residence). The writer conducted a lexical, grammatical, and contextual research of the meanings included in the "shabida" lafaz, where the meaning of "witnessing" or "knowing" also falls within the scope of the shabida meaning, and that meaning is felt to be more in line with maqashid shari'ah.Witnessing and knowing the coming of the month of Ramadan is the condition of someone who gains knowledge and beliefthat the month of Ramadan has come. Those knowledge and belief can be obtained through rukyat (the physical sighting of the moon) or hisab (calculation). However, because the word "shabida" is related to the word "shahr", it is not appropriate if the method used is rukyat because "shabr" means month in terms of numbers, not months in terms of objects. Therefore, in this context, the right way is hisab (calculation) because hisab is a method / way of knowing the coming of the month of Ramadan with numbers / counting.Thus, the cue given by Allah in the verse 185 of Al-Baqarah is an order to know the coming of Ramadan by doing hisab (calculation)
\end{abstract}

Keywords: Ramadan fasting obligations,"shahida", hisab.

\begin{abstract}
Abstrak. Tulisan ini berisi kajian semantic tentang ayat 185 surat al-Baqarah. Sebagaimana diketahui bahwa syari'at puasa dijelaskan Allah SWT melalui surat alBaqarah ayat 183-185. Pada ayat 183 Allah SWT menjelaskan kewajiban puasa bagi orang beriman; ayat 184 berisi penjelasan tentang hari-hari di mana kewajiban puasa itu harus dijalani; dan ayat 185 mengisyaratkan bagaimana cara mengetahui datangnya bulan Ramadan sebagai bulan kewajiban berpuasa. Para mufassirin memahami ayat 185
\end{abstract}


al-Baqarah sebagai keterangan tentang keadaan seseorang yang hadir (menemui) bulan Ramadan maka wajib atasnya berpuasa. Pemahaman tersebut berangkat dari kata "syahida" yang dimaknai "hadir" atau "berada" (di negeri tempat tinggalnya). Penulis melakukan penelitian secara leksikal, gramatikal dan kontekstual dari makna yang tercakup dalam lafaz "syahida", di mana makna "menyaksikan" atau "mengetahui" juga masuk dalam cakupan makna syahida dan makna itu dirasa lebih sesuai dengan maqashid syariah. Menyaksikan atau mengetahui datangnya bulan Ramadan adalah keadaan seseorang yang dengan keadaan itu ia memperoleh pengetahuan dan keyakinan telah datang bulan Ramadan. Pengetahuan dan keyakinan itu bisa dipeoleh melalui cara rukyat dan atau hisab. Tetapi karena kata "syahida" berhubungan dengan kata "syahr", maka tidak tepat jika cara yang dipakai adalah rukyah. Sebab, "syahr" artinya bulan dalam arti bilangan, bukan bulan dalam arti bendanya. Maka dalam konteks ini, cara yang tepat adalah hisab karena hisab adalah metode/cara mengetahui datangnya bulan Ramadan dengan bilangan/menghitung. Dengan demikian, isyarat yang diberikan Allah SWT dalam ayat 185 al-Baqarah itu ialah adanya perintah hisab untuk mengetahui datangnya bulan Ramadan.

Kata kunci: Kewajiban puasa Ramadan, "syabida", hisab

\section{Pendahuluan}

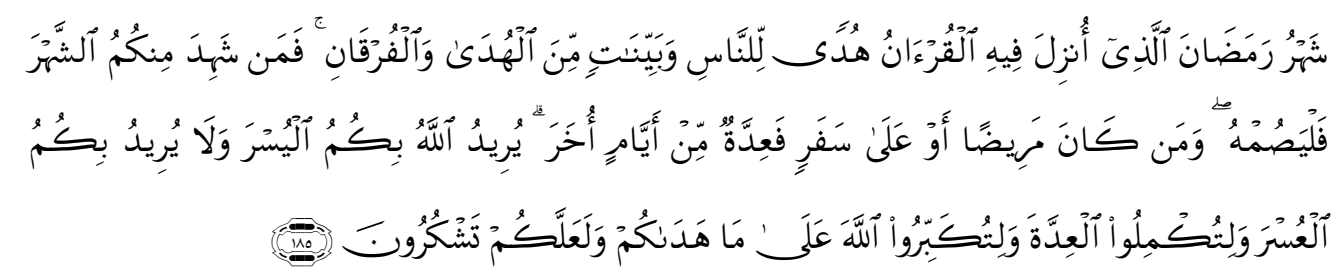

(Beberapa hari yang ditentukan itu ialab) Bulan Ramadan, Bulan yang di dalamnya diturunkan (permulaan) Al Quran sebagai petunjuk bagi manusia dan penjelasan-penjelasan mengenai petunjuk itu dan pembeda (antara yang bak dan yang bathil). Karena itu, barangsiapa di antara kamu hadir (di negeri tempat tinggalnya) di Bulan itu, maka bendaklah ia berpuasa pada Bulan itu. Dan barangsiapa sakit atau dalam perjalanan (lalu ia berbuka), maka (wajiblab baginya berpuasa), sebanyak hari yang ditinggalkannya itu, pada hari-hari yang lain. Allah SWT menghendaki kemudahan bagimu, dan tidak menghendaki kesukaran bagimu. Dan hendaklah kamu mencukupkan bilangannya dan bendaklah kamu mengagungkan Allah SWT atas petunjuk-Nya yang diberikan kepadamu, supaya kamu bersyukur. (QS. Al-Baqarah : 185)

Ayat di atas sangat populer di kalangan kaum muslimin. Setiap bulan Ramadan hampir setiap masjid di Indonesia para imam/muballigh membaca ayat tersebut. Tetapi jarang bahkan penulis belum pernah mendengar penceramah atau ustadz yang membahas secara mendalam makna kata "syahida"

${ }^{1}$ Tim Cordoba, Al-Qur'anul Karim, Tafsir Tematik, Ayat-Ayat Piliban, Terjemahan Per-Kata, Dan Tajwid Metode Warna (Bandung: Cordoba, 2016), 53. 
dalam ayat 185 itu. Mereka mencukupkan makna syahida sebagaimana tertulis dalam kebanyakan terjemahan atau tafsir yang ada dalam berbagai kitab, yakni "hadir (di negeri tempat tinggalnya)". Frasa "di negeri tempat tinggalnya" di tempatkan di dalam kurung dimaksudkan sebagai penjelas dari kata "hadir" yang memang bukan makna dominan dari lafaz "syahida". Dari penelusuran penulis terhadap kitab-kitab tafsir, semuanya memberikan penjelasan makna "syahida" sebagaimana penulis sebutkan, yakni berada dalam bulan itu. Misalnya saja, AlQur'anul Karim, Tafsir Tematik Ayat-ayat Pilihan, Terjemahan Per-kata terbitan Cordoba-Bandung. Dalam kosa katanya diartikan "dia menyaksikan" tetapi dalam terjemahan ayat diartikan "berada". Begitu pula dalam kitab-kitab tafsir yang lain.Tidak ada penjelasan khusus pada ayat ini kecuali hanya untuk menunjukkan bahwa kewajiban puasa di bulan Ramadan itu dibebankan kepada orang yang tidak dalam keadaan sakit, atau dalam bepergian. Orang yang tidak dalam keadaan sakit atau bepergian berarti orang itu berada di kampung/kotanya wajib berpuasa. Tidak ada qadha baginya. Dari sini lalu ramai penjelasan tentang berbagai keadaan manusia yang boleh qadha, seperti ibu hamil, menyusui, pekerja berat, dan lain-lain. Penjelasan tentang kewajiban orang yang berada di bulan Ramadan dimana dia tidak sakit atau musafir, menurut hemat penulis. sudah dijelaskan oleh ayat 183. Tetapi yang menjadi penting untuk dikaji lebih lanjut adalah mengapa Allah SWT menggunakan lafaz "syahida" yang dihubungkan dengan "syahr". Di antara kedua kata itu diletakkan kata "min kum".

Untuk memahami maksud keseluruhan dari ayat 185 ini penulis membuat sistematisasi kandungan ayat sebagai berikut :

Pertama, pada awal ayat Allah SWTmenjelaskan tentang: a) bulan Ramadan adalah bulan diwajibkannya berpuasa bagi orang beriman, dan; b) keistimewaan bulan Ramadan sebagai bulan diturunkannya Alquran.

Kedua, pada pertengahannya berisi penjelasan tentang: a) cara mengetahui datangnya bulan Ramadan; b) perintah berpuasa di bulan Ramadan bagi orang yang menemui bulan itu; c) orang yang uzur berpuasa dan solusinya; d) pernyataan kasih-sayang Allah SWT, dan e) perintah menghitung jumlah hari dalam bulan Ramadan.

Pada akhir ayat Allah SW'T memerintahkan umat Islam untuk bersyukur: a) atas nikmat Allah SWT berupa dijadikannya bulan Ramadan sebagai bulan istimewa melebihi bulan-bulan lainnya dan nikmat tersebut tidak diberikan kepada umat nabi-nabi terdahulu; b) nikmat kasih sayang Allah SWT yang telah memberikan solusi manusiawi bagi orang-orang yang tak mampu berpuasa pada bulan Ramadan karena uzur, dan; c) Allah menghendaki kemudahan dalam menjalankan syari'at agama-Nya. 
Berdasarkan penjelasan di atas, penulis menduga bahwa ada maksud lain yang lebih kontekstual dari gramatika Alquran agar pelaksanaan ibadah puasa di bulan Ramadan bagi umat Islam itu mudah, baik dalam menjalani ibadahnya, maupun dalam menentukan kapan datangya bulan Ramadan itu.

Jika perintah untuk mengetahui bulan Ramadan dengan cara rukyat adalah sesuatu yang sudah jelas karena dalilnya sharih, tetapi perintah hisab adalah sesuatu yang perlu diperjelas karena dalilnya 'isyary. Penulis melihat adanya perintah hisab secara 'isyary dalam surat al-Baqarah ayat 185. Melalui tulisan ini penulis mencoba mengungkap isyarat itu sehingga bisa diketahui maksudnya secara jelas.

\section{Makna Leksikal}

Yang penulis maksudkan dengan makna leksikal dalam pembahasan ini adalah makna kata berdasarkan yang sebenarnya. Makna leksikal ini bersifat tetap dan tidak terikat dengan kata lainnya (berdiri sendiri). Makna leksikal sering disebut makna yang tersebut dalam kamus. Dalam kaitan dengan ayat 185 alBaqarah ini, maka secara leksikal kata "syahida" bermakna menyaksikan. Dari berbagai kamus yang ada, maka selalu menampilkan makna "menyaksikan" sebagai makna utama dari kata "syahida". Itu sebabnya penulis memilih makna "menyaksikan" sebagai makna utama atau yang dominan dari kata "syahida" pada ayat tersebut. Jika makna utama dan dominan bisa memberikan penjelasan yang akurat, maka makna tersebut harus didahulukan karena yang demikian itu adalah yang dikehendaki oleh sebuah ungkapan. Pemaknaan kata syahida dengan "berada" sebagaimana yang ada dalam berbagai kitab tafsir bukanlah makna leksikal, melainkan makna gramatikal ${ }^{2}$ atau kontekstual ${ }^{3}$.

Penggunaan makna leksikal dari kata suahida dapat dilihat pada berbagai ayat. Muhammad Fu'ad Abdul Baqi dalam kitab Mu’jam memerinci bahwa Allah SWT menggunakan kata "syahida" dengan bermacam-macam derivatnya itu dalam 160 ayat yang tersebar dalam berbagai surat. Dari ayat-ayat itu, banyak sekali para penafsir menggunakan makna "menyaksikan/memberi keterangan/mengetahui" sebagai padanan arti kata "syahida". Misalnya saja pada surat Fushilat ayat 20 :

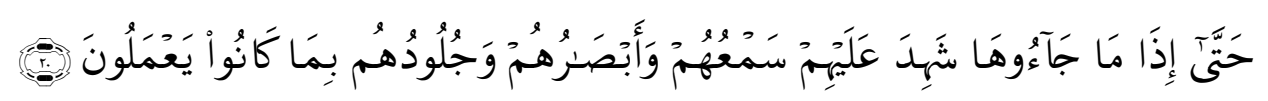

\footnotetext{
${ }^{2}$ Yang dimaksud makna gramatikal adalah makna yang berubah-ubah sesuai dengan konteks

${ }^{3}$ Makna kontekstual adalah makna kata yang diperoleh dari situasi di mana saat sebuah kalimat diujarkan. Makna ini juga sering disebut maka pragmatis.
} 
Sehingga apabila mereka sampai ke neraka, pendengaran, penglihatan dan kulit mereka menjadi saksi ${ }^{4}$ terbadap mereka tentang apa yang telah mereka kerjakan.

Demikian pula dalam surat Yusuf ayat 81:

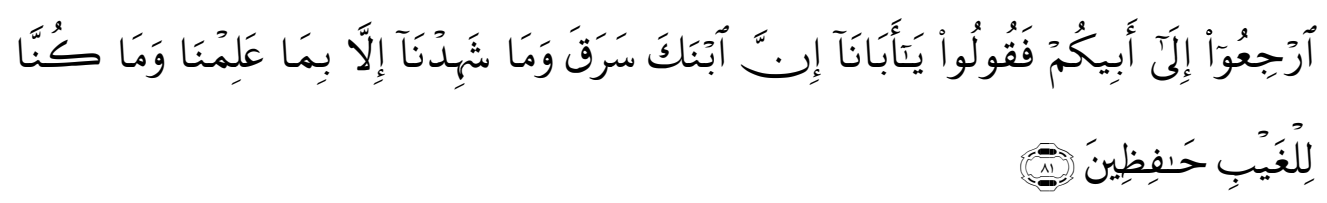

Kembalilab kepada ayahmu dan katakanlab: "Wahai ayah kami! Sesunggubnya anakmu telah mencuri, dan kami hanya menyaksikan" apa yang kami ketabui, dan sekali-kali kami tidak dapat menjaga (mengetahui) barang yang ghaib.

Ayat-ayat Alquran yang menggunakan kata "syabida" dengan berbagai derivatnya oleh para ahli tafsir diartikan dengan "menyatakan, mengakui, menyaksikan, menjadi saksi", yang pada intinya memiliki pengertian sama yaitu adanya "pengetahuan/pemahaman" dimana dengan pengetahuan/pemahaman itu seseorang memberikan keterangan/pengakuan/persaksian/pernyataan/ pembenaran tentang sesuatu untuk memberi keyakinan kepada pihak lain. Itu artinya bahwa penggunaan makna secara leksikal sudah biasa dilakukan ketika makna tersebut telah cukup memberikan penjelasan tentang masud ayat.

\section{Makna Gramatikal dan Kontekstual}

Sebagaimana telah penuulis jelaskan bahwa para penafsir/penerjemah mengartikan kata "syahida" dengan arti "hadir/berada". Pemaknaan di sini adalah makna gramatikal dan kontekstual. Karena makna "hadir/berada" masih belum jelas bahkan mengandung keraguan. Oleh karena itu perlu adapenjelasan dalam kurung "di negeri tempat tinggalnya".

Selama ini pemaknaan kata "syahida" dengan "hadir/berada" tidak pernah diperbincangkan oleh kaum muslimin karena penuturan dari buku-buku tafsir menjelaskan demikian. Penulis mencoba mengemukakan pemaknaan lain yang masih dalam lingkup makna kata "syahida" agar tidak perlu ada penambahan penjelasan lagi dalam kurung.

Menurut hemat penulis, jika pada ayat 183 Allah SWT menjelaskan kewajiban berpuasa, ayat 184 berisi penjelasan tentang hari-hari kapan kewajiban berpuasa itu harus dijalani, maka pada ayat 185 adalah menjelaskan bulan apa kebenaran.

${ }_{4}$ Maksudnya memberikan keterangan yang sebenarnya/membenarkan/menyatakan

${ }^{5}$ Maksudnya menyatakan sesuatu yang diketahui, yakni kebenaran 
dan bagaimana cara mengetahui awal masuknya bulan Ramadansebagai syarat sahnya ibadah puasa. Penulis mengartikan demikian karena dalam kamus-kamus bahasa Arab, kosa kata "syabida" selain memiliki makna "hadir" juga mengandung makna "menyaksikan/mengetahui/memberi keterangan".

Penulis mencoba menggunakan maknaleksikal kata syahida, yakni "mengetahui/memberi keterangan/menyaksikan" yang memang masih dalam lingkup makna "syahida" dengan maksud untuk memperjelas maqashid syariah-nya serta menambah wawasan.Apabiladigunakan makna "mengetahui/menyaksikan" sebagai terjemahan dari kata "syabida"dalam ayat 185, maka penggalan ayat :

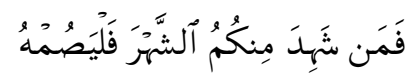

terjemahannya menjadi:

"Barangsiapa di antara kamu sudah mengetahui/menyaksikan bulan itu, maka hendaklah ia berpuasa pada Bulan itu".

Penggunaan makna "mengetahui/menyaksikan" terasa lebih kontekstual dan lebih tepat karena kata "syabida" dalam ayat itu berhubungan dengan kata "syahr". Allah SWT menggunakan kata "syabr" untuk menunjuk bulan Ramadan dan bulan-bulan lain guna menunjukkan waktu-waktu pelaksanaan ibadah bulanan dalam Islam. Hal itu menurut penulis mengandung implikasi bahwa untuk mengetahui/memberi keterangan yang sebenarnyatentang datangnya bulan-bulan ibadah ialah dengan menggunakan perhitungan. Sebab, kata "syahr" berarti bulan dalam art bilangan, bukan bendanya. Jika yang dituju itu bulan dalam arti benda langit, maka lafaz yang digunakan adalah "qamar". Itu artinya, jika akan mengetahui/meyakini datangnya bulan-bulan ibadah, secara implisit Allah SWT memerintahkan untuk melakukan perhitungan, bukan dengan melihat Bulan. Hal ini penting untuk diperhatikan karena menurut Al-Qardhawi bahwa puasa itu dilakukan setelah adanya kepastian masuknya bulan Ramadan dengan cara yang memungkinkan dan dapat dilakukan oleh banyak orang, yang tidak membebani dan memberatkan mereka dalam agama. ${ }^{6}$ Kemudahan dalam menjalankan syari'at adalah sesuai dengan maksud ayat ini dan memjadi fitrah agama Islam.

Betul memang, Nabi dan para sabahat beliau tidak melakukan perhitungan (hisab) untuk mengetahui/meyakini datangnya "syahr"Ramadan itu. Beliau memerintahkan para sahabat untuk melakukan ru'yat.Yang demikian itu karena adanya kelemahan/kekurangan pada diri kaum muslimin saat itu yang belum mampu melakukan perhitungan kapan bulan Ramadan tiba. Kelemahan/kekurangan tersebut dinyatakan sendiri oleh Rasulullah dalam sabda beliau :

${ }^{6}$ Yusuf Qardhawi, Pengantar Studi Hadits (Bandung: CV. Pustaka Setia, 2007), 227-28. 


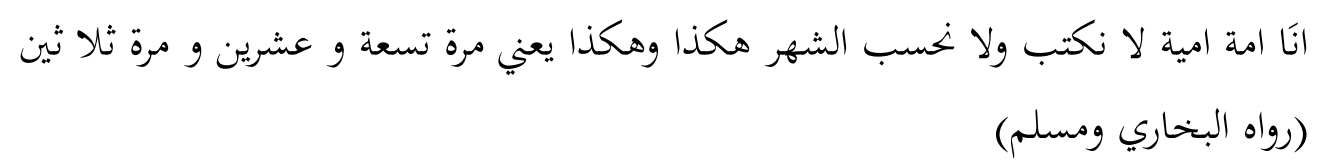

"Sesunggubnya kami adalah umat yang "ummi"; kami tak bisa menulis dan melakukan perhitungan. Bulan itu adalah demikian-demikian. Kadang-kadang dua pulub sembilan hari, dan kadang-kadang tiga pulub hari. (HR. Bukhary - Muslim)

Para ahli hukum Islam menyatakan bahwa kelemahan umat Islam saat itu disebut sebagai 'illat atau alasan hukum mengapa rukyat diperintahkan.Dalildalil yang berkenaan dengan perintah merukyat cukup sahih dan sharih. Dalildalil tersebut semuanya hadits Rasul. Tidak ada satu pun ayat yang memerintahkan merukyat. Sungguh sangat bijaksana Rasulullah memerintahkan sesuatu yang memang baru bisa dilakukan umat saat itu, yakni rukyat. Jika perintahnya lebih dari itu, hisab misalnya, tentu tidak bisa dilaksanakan oleh umat.

\section{'Illat al-hukm ${ }^{8}$}

Sesungguhnya Tllat hukum perintah rukyat sebagaimana ditunjukkan oleh hadits Rasulullah adalah adanya kelemahan pada kaum muslimin dalam bidang ilmu pengetahuan. Tllat ini diakui sendiri oleh Rasulullah saw. dalam sabdanya bahwa umat Islam ketika itu adalah umat yang ummiy, yang lemah dalam bidang ilmu hitung (hisab). Rasulullah memerintahkan rukyat agar umat tidak mengalami kesulitan dalam mengawali dan mengakhiri ibadah puasa Ramadan. Dalam pada itu, di kalangan masyarakat Arab memang sudah berkembang tradisi rukyat untuk mengetahui pergantian bulan qamariah.Mereka melakukan rukyat untuk mengetahui saat terjadinya Bulan purnama di mana mereka akan melakukan ritual atau persembahan. Dan ketika berhasil merukyat, mereka meneriakkan "hilal" sebagai ungkapan kegembiraan bahwa Bulan baru telah tiba ${ }^{9}$.

${ }^{7}$ Muhammad ibn Isma'il ibn Ibrahim ibn al-Mugirah al-Bukhari, Shahih Al-Bukhari (Riyadh: Maktabah al-Ma'arif, 1997), j. 2, 281.; Muslim bin al-Hajjaj al-Naisaburi, Sabib Muslim (Beirut: Dar Ihya al-Turats Arabi, n.d.), j. 5, 482.

${ }^{8}$ 'Illatul Hukmi adalah hasil penalaran seseorang tentang alasan suatu perintah atau larangan mengapa hal itu disyariatkan. Lihat: Abdul Wahab Khalaf, Tlmu Usul al-Figh (Kairo: Maktabah al-Da'wah al-Islamiyyah, 1972), 55.

${ }_{9}^{9}$ Dalam sebuah hadis disebutkan bahwa apabila berhasil melihat hilal, Rasulullah saw. menuntun kita untuk bertakbir tiga kali seraya berdoa :'Ya Allah SWT, telah nampak hilal atas kami dengan aman dan iman, dengan keselamatan dan keislaman. Allah SW'T adalah Tuhanku dan Tuhanmu (semua manusia). Lihat Moh. Murtadho, Ilmu Falak Praktis (Malang: UIN-Malang Press, 2008), 273. 
Ketika zaman telah bertukar dan kaum muslimin pun telah mampu menguasai ilmu pengetahuan dan teknologi, berarti illat hukum pada perintah tersebut telah hilang. Dalam kaidah fikih dinyatakan bahwa hukum itu berkisar kepada 'illatnya. Ada atau tidak adanya hukum bergantung kepada 'illat. Maka, jika illat hukum itu sudah tidak ada, harus ditentukan hukum baru yang lebih memberi maslahat dan kemudahan kepada umat.

\section{Tujuan Penggunaan Kata}

Hadits-hadits Rasul yang berhubungan dengan perintah untuk mengetahui awal dan akhir bulan ibadah menggunakan kata ra'a. Kata ra'asebagai kata dasar dari rukyat yang berarti melihat, penggunaannya dalam khazanah hukum Islam lebih mengarah kepada pengertian "melihat dengan akal", bukan "melihat dengan mata kepala". Dari kata ra'ayang derivat diantaranya "rakyu" adalah menunjukkan kepada arti penggunaan akal pikiran dalam menalar suatu masalah.

Di dalam Alquran maupun Hadits Nabi, pemahaman makna dasar ra'adengan arti "melihat dengan akal" adalah lebih dominan dan lebih rajih dibandingarti "melihat dengan mata kepala". Meskipun kata ra'aitu dapat diartikan melihat, tetapi alat driya yang diperintah untuk digunakan adalah akal, bukan mata. Misalnya sabda Nabi Muhammad saw. : Man ra'a minkum munkaran fal yughayyir bi yadih..." ("Barang siapa "melihat" kemungkaran hendaknya ia mencegah dengan tangannya...").

Pada hadits Rasul yang lain beliau bersabda: Shallu kama ra'aitumuni ushalli (Salatlah kamu seperti halnya kamu melihat aku salat). Kata ra'a pada hadis di atas bisa diamalkan oleh para sahabat waktu itu. Tetapi untuk sekarang, tidak mungkin bisa dilakukan oleh umat Islam karena Nabi sudah tiada. Maka, makna ra'a pada hadis tersebut tentu mengetahui/memahami.

Begitu pula penggunaan lafaz ra'a dalam Alquran selalu menunjuk kepada arti melihat dengan akal, seperti surat al-Ma'un, surat al-Fiil.Maka, arti yang tepat pada hadits-hadits yang berkenanaan dengan rukyat adalah "mengatahui"; bukan cuma melihat. Oleh sebab itu, perintah dengan kata dasar ra'a akan lebih tepat bila diartikan "pikirkan" atau "pahamkan". Adapun lafaz yang dipakai untuk menunjukkan dominasi perintah "melihat dengan mata kepala" adalah kata nadhara

Dengan demikian, dapat kita pahami bahwa makna kata "rukyat" pada beberapa hadits Rasul yang berkaitan dengan kewajiban berpuasa, menurut tujuan penggunaan kata dapat berarti - atau bahkan lebih pas apabila diartikan dengan - rukyah bil aqli (melihat dengan akal = melakukan hisab), bukan "rukyah bil fi'li" (melihat dengan mata kepala = observasi). Adapun rukyah bil fi'li yang dilakukan oleh Nabi dan para sahabatnya adalah peragaan dari salah satu aspek makna yang kurang dominan dari cakupan makna kata rukyat karena 
keterbatasan kemampuan mereka saat itu untuk melaksanakan aspek makna yang lebih dominan dan lebih rajih.

\section{Perbedaan Pemahaman Solusi}

Secara sharih hadits-hadits Rasul memerintahkan rukyat untuk mengetahui awal dan akhir Ramadan. Jika rukyat tak berhasil, karena mendung sehingga Bulan tertutup awan, hendaknya di istikmal - kan atau di kadar kan ${ }^{10}$. Itulah solusi yang diberikan oleh Rasulullah saw.

Hal yang demikian itu oleh sebagian umat menjadi sebab tidak jelasnya persoalan. Mereka berbeda dalam memahami solusi yang diberikan Nabi. Pada hadis pertama :

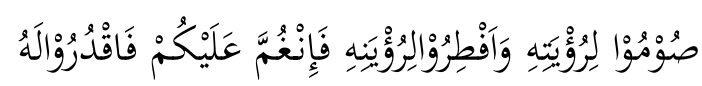

"Berpuasalah kamu karena melihat bulan, dan berbukalah kamu karena melihat bulan, jika ternyata bulan tertutup atasmu, maka kira-kirakanlah."

Jumhur fuqaha berpendapat bahwa kata فَاقْدُرُوَالهُ (kira-kirakanlah) berarti "sempurnakanlah bilangan menjadi 30 hari". Tetapi fuqaha ${ }^{11}$ yang lain berpendapat bahwa maksudnya "kira-kirakanlah dengan memakai hisab (perhitungan)". Maka, hadits ini oleh para ahli hisab dijadikan sandaran adanya perintah untuk melakukan hisab.

Jumhur fuqaha menafsirkan kata فَاقْدُرُوْاَله dengan istikmal karena mereka menghubungkannya dengan hadits shahih dari Ibnu Abbas ra., bahwa Nabi Saw bersabda:

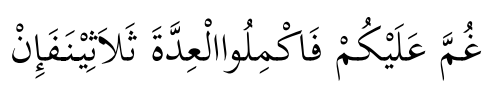

"Iika ternyata bulan tertutup atasmu, maka sempurnakanlah bilangan menjadi tiga puluh hari."

Sementara itu Imam Abu al-Abbas Ibnu Suraij (306 H/918 M), seperti dikutip oleh Ibn al-'Arabi, mengambil langkah lain, yaitu dengan

10 "Janganlah kamu berpuasa sebelum melihat hilal dan jangan beridulfitri sebelum melihat hilal. Jika Bulan tertutup awan, maka kadarkanlah". Lihat, al-Bukhari, Shahih Al-Bukhari, j. 2, 281, hadis no. 1909.; al-Naisaburi, Sabih Muslim, j. 5, 482, hadis no. 1080.

${ }^{11}$ Diantara Fuqaha yang berpendapat demikian adalah: Mutharrif bin Abdillah (tabi'in) dan Ibnu Qutaibah (ahli Hadits). baca di Susiknan Azhari, Hisab Dan Rukyab Wacana Untuk Membangun Kebersamaan Di Tengah Perbedaan (Yogyakarta: Pustaka Pelajar, 2007), 57. 
mengompromikan dua hadis yang berlainan lafaznya itu. Ia mengatakan bahwa hadis Nabi saw yang menggunakan lafaz "faqduru labu" merupakan khitab yang ditujukan pada orang-orang yang khusus memiliki kemampuan hisab, sedangkan sabda Nabi saw "fa akmilu al-'iddah adalah yang ditujukan bagi masyarakat umum. $^{12}$

Jelasnya, perintah men-kadar-kan tentunya hanya akan bisa dilakukan oleh para ilmuan ${ }^{13}$. Sebaliknya, perintah istikmal dapat dilakukan oleh siapa saja. Keduanya, istikmal maupun mengkadarkan, adalah cara-cara untuk menghilangkan keragu-raguan antara "telah" dan "belum" masuk bulan baru. Keraguan itu datang pada tanggal 29 Sya'ban dan 29 Ramadan. Apakah malam itu tanggal 1 bulan baru atau tanggal 30 bulan yang sedang berjalan ${ }^{14}$. Hal ini penting untuk ditegaskan karena untuk mengawali dan mengakhiri ibadah puasa umat Islam dituntut memiliki kepastian/keyakinan atau paling tidak dugaan yang kuat bahwa hilal telah wujud sebagai tanda awal bulan baru, dan itu merupakan syarat syar'i kewajiban berpuasa. Bagi orang awam, kepastian itu muncul melalui istikmal, sedangkan bagi ilmuan muncul dengan cara meng"kadar'kan (menghisab). Maka. ketika para ilmuan (ahli hisab) telah menghitung dengan teliti, dan dari hasil perhitungannya mereka menyatakan bahwa hilal sudah wujud, sekalipun tidak bisa dirukyat, keterangan mereka lebih layak untuk diterima. Keterangan para ahli hisab dapat dikatakan sebagai saksi ahli yang patut didahulukan untuk dijadikan dasar dalam menetapkan awal bulan qamariah.

Sebagai tambahan, bagi daerah yang beriklim tropis seperti Indonesia, kondisi kelembaban udaranya relatif tinggi, cuaca selalu mendung, atau paling tidak di kaki langit diliputi awan. Akibatnya, kegiatan rukyat mengalami gangguan. Jika dalamsituasi seperti itu umat Islam selalu memilih rukyat dan istikmal, maka akan terjadi kekeliruan dimana nanti akan terjadi suatu bulan hanya berumur 28 hari. Padahal, sekali lagi, kemungkinan hilal tertutup awan/mendung, di Indonesia sangat besar. Itu artinya bahwa rukyat akan sering menemui kendala dan kemungkinan keberhasilan rukyat amat kecil.Oleh karena itu, kita harus memilih alternatif kedua, yaitu meng-kadar-kan atau melakukan hisab.

12 Ibid.

${ }^{13}$ Al-Imam An-Nawawi, Al-Majmu' Syarb al-Mubazdzdab (Madinah: Al-Maktabah alSalafiyah, n.d.), j. 6, 270.

${ }^{14}$ Perlu diketahui bahwa pergantian hari dalam kalender Qamariyah dimulai semenjak terbenam Matahari. Berbeda dengan kalender Masehi yang pergantian harinya dimulai tengah malam, atau jam 00 . 


\section{Mathla'}

Secara leksikal, mathla' berarti tempat terbit (bulan). Yang dimaksud tempat terbit di sini adalah wilayah yang sudah bisa menyaksikan datangnya bulan Ramadlan sebagai syarat wajibnya berpuasa.Di kalangan para ahli belum satu kata dalam menetapkan mathla' tentang batasan wilayah berlakunya hasil rukyah/hisab suatu tempat. Ada yang membatasi hasil rukyah/hisab suatu tempat hanya berlaku untuk satu wilayah hukum (negara). Sebagian lagi berpendapat bahwa rukyah/hisab suatu tempat berlaku untuk seluruh dunia.

Berkenaan dengan mathla' ini, ada satu peristiwa terjadi pada masa sahabat yang bisa dijadikan referensi untuk menyikapi masalah ini. Diceritakan oleh Kurebbahwa Ummul Fadhal binti Al-Harits telah mengutusnya menemui Mu'awiyah di Syam. Kureb berkata: "Aku telah sampai di Syam lalu menyelesaikan tugasku menyampaikan pesan Umul Fadhal (kepada Muawiyah). Di sana aku melihat hilal Ramadlan. Aku melihatnya pada malam Jum'at. Selanjutnya aku kembali ke Madinah dan sampai di Madinah akhir bulan (Ramadan). Waktu itu Abdullah bin Abbas sedang membicarakan tentang hilal. Ia kemudian bertanya kepadaku: "Kapan kamu dan kawan-kawanmu melihat Hilal?" Aku menjawab: "Kami melihat Hilal pada malam Jum'at". Ia menegaskan kepadaku: "Apakah kamu sendiri melihat Hilal itu?". "Ya", jawabku. "Orang-orang lain juga melihatnya. Mereka dan Mu'awiyah lalu berpuasa." Abdullah bin Abbas lalu melanjutkan perkataannya: "Tetapi kami melihat hilal pada malam Sabtu kemudian kami berpuasa setelah kami ber istikmal'(menyempurnakan Sya'ban 30 hari). Aku kemudian bertanya kepadanya: "Apakah kalian (di Madinah) tidak mencukupkan dengan rukyatnya Mu'awiyah di Syam?" Abdullah bin Abbas menjawab: "Tidak, demikian inilah perintah Rasulullah saw". (HR. Muslim)

Meskipun telah ada dalil seperti di atas, dalam masalah mathla' ini para ahli fikih masih berbeda pendapat. Menurut Abdurrahman al-Jaziri dalam kitab Fiqh 'ala al-Madzhahib al-Arba'ah, dari empat madzhab fiqih yang terkenal, tiga diantaranya yaitu Mazhab Hanafi, Mazhab Maliki, dan Mazhab Hambali cenderung kepada rukyat global; yaitu jika satu tempat telah berhasil melihat hilal atau sudah memasuki awal Ramadan, maka hal itu berlaku untuk kaum muslimin di seluruh dunia. Adapun menurut Mazhab Syafi'i,mereka lebih cenderung kepada rukyah local. Artinya, hasil rukyat/hisab hanya berlaku untuk satu mathla'yang wilayahnya \pm radius 24 farsakh $( \pm 120 \mathrm{Km}) .{ }^{15}$

${ }^{15}$ Abd Ar-Rahman al-Jaziri, Kitab Figh 'Ala Mazabibil Arba'Ah (Beirut: Dar al-Maktab al-'Ilmiyah, n.d.), j. 1, 500 . 
Dalam perkembangan selanjutnya, muncul pemikiran mathla'wilayatul buk $m i^{16}$. Yang dimaksud di sini adalah bahwa hasil hisab atau rukyat,jangkauan berlakunya mengikat satu wilayah kesatuan negara. Jika suatu daerah dalam sebuah Negara telah memasuki awal Ramadan, maka seluruh penduduk di Negeriitu sudah berkewajiban menjalani ibadah puasa. Pertimbangan yang dikemukakan dalam masalah ini adalah kemaslahatan. Yang demikian itu demi ketertiban administrasi dan kemudahan pelayanan kepada warga negaranya. Pemerintah berkepentingan menetapkan tanggal pelaksanaan ibadah suatu agama adalah demi kemaslahatan. Tidak mungkin pemerintah menetapkan dua tanggal yang berbeda untuk satu peristiwa keagamaan.

Berkaitan dengan masalah mathla' ini, ada baiknya dicermati ayat 185 alBaqarah. Pada ayat tersebut terdapatisyarat di mana umat Islam tidak mungkin bareng dalam memasuki awal bulan Ramadan. Ungkapan "faman syahida min kum asy-syahra" mengindikasikan kepada maksud tersebut. Ini artinya,ada sebagian umat Islam yang telah memasuki bulan Ramadan dan mereka sudah wajib memulai puasa.Sedangkan yang lain belum memasukinya, karena berbeda mathla'nya, dan mereka belum ada kewajiban berpuasa. Jadi, perbedaan tanggal dalam memulai dan mengakhiri puasa adalah suatu keniscayaan, baik menurut penjelasan ayat maupun ilmu hisab.

Permasalahannya adalah bahwa wilayah yang sudah masuk dan yang belum masuk bulan Ramadanitu bisa terjadi dalam satu wilayah hukum suatu negara. Hal ini menimbulkan kesulitan tersendiri. Karena masalah penetapan awal bulan qamariah sangat erat kaitannya dengan persoalan ekonomi, sosial, politik dan budaya, maka konsep mathla' wilayatul hukmi lebih tepat untuk diterapkan. Dengan konsep ini maka kesatuan urusan suatu Negara bisa dicapai. Karena, apabila satu daerah dalam wilayah Negara telah memasuki bulan Ramadan, maka seluruh wilayah hukum yang sama sudah wajib berpuasa.Yang demikian itu karena maslahat yang diperoleh akan lebih besar dari pada mafsadat yang bakal timbul.

\section{Fenomena Sidang itsbat}

Sidang itsbat adalah sidang yang diselenggarakan oleh pemerintah (kementerian Agama) untuk menetapkan tanggal pelaksanaan ibadah kaum muslimin yaitu tanggal satu Ramadan, satu Syawwal ('Idul Fitri), dan 10 Dzul Hijjah ('Idul Adha). Hanya untuk tiga bulan itu saja diselenggarakan sidang

${ }^{16}$ Yaitu bahwa bila hilal terlihat di mana pun di wilayah wawasan Nusantara, dianggap berlaku di seluruh wilayah Indonesia. Konsekuensinya, meskipun wilayah kita dilewati oleh garis penanggalan Islam Internasional yang secara teknis berarti bahwa wilayah Indonesia terbagi atas dua bagian yang mempunyai tanggal hijriyah yang berbeda, penduduk melaksanakan puasa secara serentak..lihat di S. Farid Ruskanda, 100 Masalab Hisab dan Rukyat: Telaab Syariah, Sains dan Teknologi (Jakarta: Gema Insani, 1996), 19. 
itsbat. Untuk bulan-bulan Hijriyah lainnya ditetapkan Menteri Agama dengan menggunakan hisab 'urfi (tanpa melalui sidang itsbat).

Dalam pelaksanaan sidang itsbat itu diundang seluruh perwakilan organisasi keagamaan dan tokoh agama. Sidang dilaksanakan di Kementerian Agama Jakarta pada setiap tanggal 29 Sya'ban, 29 Ramadan, dan 29 Dzul Qaidah sekitar pukul 19.00 WIB.Materi sidang adalah membahas laporan hasil rukyatul hilal dari para petugas yang disebar di berbagai titik observasi. Hasil sidang ini sangat ditunggu-tunggu oleh masyarakat muslim di Indonesia. Sidang ini tidak bisa dilaksanakan diwaktu lain karena harus menunggu hasil rukyat para petugas rukyat kementerian Agama di beberapa titik observasi di seluruh Indonesia yang hanya bisa dilaksanakan pada saat matahari terbenam tanggal 29 Sya'ban, 29 Ramadan, dan 29 Zulqa'dah. Lebih dari 40 titik observasi dipilih sebagai lokasi pelaksanaan rukyatul hilal itu.

Tak pelak lagi, jika penyelenggaraan sidang itsbat ini menjadi tidak kondusif dan telah menimbulkan kegamangan di kalangan masyarakat muslim, terutama mereka yang berdomisili di wilayah Indonesia Bagian Tengah(WITA) dan Indonesia Bagian Timur (WIT). Mengapa demikian?. Hal itu disebabkan karenapelaksanaan sidang itsbat ini harus menunggu hasil rukyat yang dilakukan oleh para petugas di beberapa lokasi di Indonseia Timur, Indonesia Tengah, dan Indonesia Barat.Setelah semua petugas di masing-masing lokasi melaporkan hasil rukyatnya, barulah sidang itsbatbisa dilaksanakan. Terakhir laporan yang ditunggu adalah hasil perukyat dari Sabang, Banda Aceh.

Sebagai gambaran misalnya sidang Itsbat menjelang 1 Syawwal 1438 H/2017 M. Matahari terbenam di Sabang (Banda Aceh) sebagai salah satu titik observasi hilal paling Barat pukul 18.55 WIB, di Jakarta terbenam pukul 17.50 WIB, di Ujung Pandang pukul 18.01 WITA, dan di Merauke pukul 17.30 WIT. Itu artinya, sidang Itsbat baru bisa dilaksanakan di Jakarta pukul 19.00 WIB karena harus menunggu laporan petugas rukyat dari Sabang, Banda Aceh. Ketika sidang Itsbat dilaksanakan di Jakarta pukul $19.00 \mathrm{WIB}$, di Ujung Pandang sudah pukul 20.00 WITA $=$ jam 08 malam ( sudah masuk waktu Isya') dan di Merauke sudah pukul 21.00 WIT $=$ jam 09 malam (sudah lama kelewat waktu Isya). Di sinilah kegamangan itu muncul bagi masyarakat muslim di Indonesia Tengah dan Indonesia Timur. Karena, semenjak matahari terbenam (sejak masuk waktu maghrib) mereka tidak ada kepastian; apakah malam itu sudah boleh bertakbir untuk menyambut satu Syawwal ataukah masih harus melaksanakan salat taraweh pada tanggal 30 Ramadan. Barulah setelah ada pengumuman resmi Menteri Agama \pm pukul 19.15 WIB, atau pukul 20.15 WITA di Ujung PadangMakasar, atau pukul 21.15 WIT di Merauke, ada kepastian apa yang harus mereka lakukan; melaksanakan salat taraweh atau takbiran, tergantung kepada berita sidang itsbat di Jakarta. Kegamangan seperti ini berulang setiap tahun dan 
sudah berlangsung selama puluhan tahun serta belum ada tanda-tanda akan berkahir.

Keadaan ini sungguh tidak kondusif dan tidak menguntungkan bagi pembinaan masyarakat muslim. Lebih-lebih jika terjadi perbedaan penetapan tanggal satu Syawwal. Misalnya saja malam itu diumumkan oleh pemerintah bahwa berdasarkan laporan petugas rukyatul hilal di semua titik observasi tidak ada yang berhasil melihat Hilal satu Syawwal, maka malam itu ditetapkan sebagai malam tanggal 30 Ramadan, dan satu Syawwal ditetapkan sehari berikutnya. Sementara berdasarkan hisab, bahwa Hilal sudah wujud, sehingga menurut Ilmu Falak, malam itu sudah masuk tanggal satu Syawwal. Maka, suasana yang terjadi adalah ada sebagian masyarakat yang sudah bertakbir, dan sebagian masyarakat yang lain masih melaksanakan salat tarawih. Satu masjid mengumandangkan takbir menyambut kemeriahan satu Syawwal, masjid yang satunya lagi menggemakan lantunan shalawat dan bacaan Imam salat tarawih. Pagi harinya, sebagian masyakat bersukaria menyambut kegembiraan 'Idul Fitri, sebagian yang lain menahan nafsu dari segala yang membatalkan puasa. Inilah yang terjadi dalam masyarakat muslim di Indonesia ketika terjadi perbedaan berhari Raya 'Idul Fitri. Dan ini sudah terjadi berulang kali.

Keadaan ini sangat rawan konflik internal umat beragama. Saling ejek dan saling cemooh sangat mungkin bisa terjadi di antara sesama muslim. Dan yang paling tidak kita inginkan adalah timbulnya kerancuan pelaksanaan syari'at. Ada sebagian warga muslim yang hari itu sudah tidak berpuasa, tetapi karena pemerintah mengumumkan 1 Syawwal jatuh besok paginya, maka mereka salat Idul Fitrinya dilakukan besok harinya. Sehingga, ada petugas khatib Idul Fitri yang berkhutbah dua kali. Hari pertama ia khutbah di masjid dekat rumah karena sesuai dengan keyakinannya, hari kedua ia khutbah di masjid lain karena sudah terlanjur janji dan tak mungkin dibatalkan. Keadaan ini membuat masyarakat awam menjadi binggung. Meskipun anjuran untuk saling menghormati keyakinan disuarakan pada setiap kamunitas muslim, namun tetap saja di hati masyarakat muslim tersimpan persoalan yang tidak terpecahkan; mengapa sampai begini; mana yang benar; tidak mungkin dua-duanya benar; siapa yang bertanggung jawab atas dosa umat ini, dan lain-lain. Sementara umat non-muslim tertawa dan mencemooh serta mencibir dalam hati: "Umat Islam, bagaimana mereka akan mengurus urusan yang besar, ngurus waktu ibadahnya saja tidak becus!".

Namun ironisnya, keadaan seperti itu belum ada tanda-tanda akan berakhir. Meskipun usaha untuk penyatuan persepsi terus diupayakan, tetapi karena masing-masing memegangi "egonya" sendiri-sendiri sehingga usaha itu belum membuahkan hasil. Barangkali model sidang Itsbatnya perlu diformat ulang. Sebab, jika sidang Itsbat masih seperti itu-itu saja, maka kekuatiran akan terjadi perbedaan berhari raya masih akan tetap menghantui masyarakat muslim. 
Yang penulis maksud format sidang Itsbat itu adalah bahwa pelaksanaannya tidak dengan menunggu laporan rukyatul hilal. Sehingga, sidang Itsbat tidak dilaksanakan di akhir Sya'ban, akhir Ramadan, atau akhir Dzul Qaidah, tetapi dilaksanakan di akhir tahun menjelang tahun baru. Pelaksanaannya juga tidak mesti di Jakarta, tapi bisa di mana saja, bahkan kapan saja, karena materi yang akan disidang bukan berupa laporan pandangan mata yang terikat pada waktu dan tempat, melainkan hasil olah otak para ahli hisab yang tidak kenal dimensi tempat dan waktu. Oleh sebab itu, sidang Itsbat tidak diburu waktu dan tidak disertai dengan rasa kekuatiran. Hasil sidang Itsbat nantinya berupa hasil kesepakatan ulama, para ahli dan pemerintah berupa tanggal pelaksanaan ibadah bulanan dan tahunan kaum muslimin untuk satu tahun ke depan. Hasilnya dipubilaksikan kepada masyarakat berupa kalender selama satu tahun. Hari-hari besar dan hari-hari ibadah umat Islam ditulis dengan hurup tebal dan dengan warna merah sebagaimana hari-hari libur lainnya. Tidak perlu lagi ada catatan dalam kalender "tanggal satu syawwal menunggu pengumuman pemerintah". Masyarakat tinggal melihat almanac/kalender tersebut dengan jelas dan dengan perasaan tenang serta dapat menyiapkan diri menyambut hari-hari keagamaan yang mereka tunggu-gunggu. Jika cara ini ditempuh, kekuatiran umat Islam bakal terjadi perbedaan dalam menyambut hari Raya umat Islam akan bisa dihindarkan, dan ukhuwah islamiyah dan wathaniyah bisa diperkuat, Insya Allah SWT'.

Memang solusi yang penulis tawarkan ini mengabaikan rukyah. Penulis tidak bermaksud mengabaikan hadits Nabi yang sahih dan sharih tentang perintah rukyah. Tetapi bukankah khalifah Umar pernah mengabaikan makna tekstual yang dikandung dalam surat al-Hasyar ayat 7 dan mengutamakan makna kontekstaulnya demi memperoleh maslahat yang lebih besar? Apa yang Umar lakukan itu tidak dilakukan oleh Nabi. Padahal, Umar sahabat Nabi. Jarak antara Nabi wafat dengan tindakan Umar belum cukup 15 tahun. Umar mengambil tindakan yang berbeda dengan Nabi karena keadaannya sudah tidak sama. Inilah yang dijadikan alasan ahli fikih bahwa "perbedaan waktu dan tempat mengakibatkan perubahan hukum". Dalam kaidah fikih dinyatakan "Hukum itu berlaku menurut ada atau tidak adanya "illat dan sebabnya" ${ }^{17}$ Jika contoh itu kita gunakan untuk menyelesaikan persoalan hisab rukyat; mengapa kita keberatan berpindah metode dari rukyat kepada hisab dalam menentukan awal Ramadan? Rukyat diperintahkan Nabi 1500 tahun yang lalu ketika ilmu pengetahuan dan teknologi belum berkembang. Sekarang zaman sudah berobah, umat Islam sudah mampu memanfaatkan ilmu dan teknologi yang dapat mengetahui saat

\footnotetext{
1973), j. 4, 105.

${ }^{17}$ Ibn al-Qayyim al-Jauziyyah, I'lam al-Munaqqi'in 'an Rabbal-'Alamin (Beirut: Dar al-jil,
} 
datangnya bulan Ramadan dengan mudah. Ini adalah nikmat Allah SW'T. Mengapa nikmat ini diingkari? Bukankah perpindahan metode itu hanya berpindah dalil dari dalil yang satu kepada kepada dalil yang lain, dari makna yang sharih ke makna 'isyar? Rukyat diperintahkan melalui hadis secara sharih. Hisab diperintahkan melalui hadis dan ayat secara 'isyarat. Hisab belum mungkin diperintahkan secara sharih pada saat Nabi hidup karena hisab membutuhkan alat bantu, yaitu ilmu dan teknologi. Sekarang yang dibutuhkan untuk hisab itu sudah ada, mengapa kita masih keberatan?

Pengalaman telah berpuluh-puluh tahun pemerintah menggunakan rukyat sebagai metode menentukan awal bulan qamariyah tetapi hasilnya masih belum seperti yang diharapkan. Anggaran sudah besar dikeluarkan, tetapi masyarakat masih selalu dihantui perasaan kuatir bakal terjadi perbedaan dalam mengawali puasa dan berhari raya. Sudah saatnya sekarang pemerintah mengakhiri kekuatiran umat ini dengan berpindah kepada metode hisab. Bukan rukyat. Masih banyak kebutuhan umat yang perlu dibiayai melalui anggaran kementerian Agama. Masih banyak urusan umat yang harus diselesaikan oleh pemerintah dalam soal kehidupan beragama. Sidang itsbat cukup sekali pada akhir tahun untuk menyamakan persepsi hasil perhitungan para ahli hisab. Hal itu lebih mudah.

Adapun masyarakat muslim yang tidak puas dengan hasil sidang Itsbat model ini, mereka dipersilakan melakukan rukyat sesuai dengan keyakinannya. Keyakinan mereka harus dihormati. Yang penting mereka tidak memaksakan kehendak atau keyakinannya kepada yang lain. Dan yang lebih penting lagi, pemerintah telah mengambil peran yang tepat dalam melakukan pembinaan umat beragama; yakni memberikan pedoman yang jelas dan tegas dalam menenetapkan hari-hari besar dan hari-hari pelaksanaan ibadah umat beragama. Fahmi Amhar menilai bahwa sikap pemerintah selama ini selalu tidak bisa memposisikan diri sebagai pihak yang netral dalam menyelesaikan perbedaan yang terjadi dalam tubuh ormas-ormas khususnya kelompok ahli hisab dan ahli rukyah, sehingga keputusan itsbat sering dipengaruhi oleh fanatik paradigma yang mereka anut ${ }^{18}$. Untuk itu - sekali lagi- sudah saatnya pemerintah sekarang mengambil langkah lain yang lebih obyektif guna mendahulukan kemaslahatan yang lebih urgen, yakni membina ukhuwah umat beragama, yakni dengan hisab.

\section{Kesimpulan}

Sebagai penutup yang menjadi kesimpulan uraian ini adalah bahwa ada isyarat yang diberikan Allah SWT di dalam surat al-Baqarah ayat 185 untuk

${ }^{18}$ Fahmi Amhar, Penentuan Awal Ramadhan dengan Hisab dan Rukyah Menurut Fuqaha, http://www.hisabrukyat .co.id / diakses tanggal 16 Mei 2017. 
melakukan hisab dalam usaha mengetahui masuknya bulan Ramadan. 'Isyarat itu tertulis dalam kata "syabida" yang menurut para mufasirin diartikan "hadir" atau "berada" dalam bulan itu. Penulis memaknai kata "syabida" dengan "menyaksikan atau mengetahui". Pemaknaan yang demikian ini adalah pemaknaan secara leksikal. Pemaknaan kata "syahida" dengan menyaksikan atau mengetahui berimplikasi kepada harus adanya cara untuk menyaksikan atau mengetahui awal bulan Ramadan. Cara itu adalah rukyat atau hisab. Karena kata "syahida" dalam ayat itu berhubungan dengan kata "syahr", maka tidak mungkin cara tersebut rukyah, tetapi adalah hisab. Kesimpulan seperti ini diambil dengan memperhatikan konteks kalimat dengan keadaan umat ketika ayat diturunkan.

Selanjutnya, antara kata "syahida" dengan kata "syahr" dikelangi oleh kata "minkum". Kata "minkum" ini mengisyaratkan bahwa awal bulan Ramadan tidak mungkin bisa disaksikan oleh orang sedunia secara berbarengan.Yang demikkian ini adalah pemaknaan secara gramatikal. Maksudnya, bahwa secara redaksional ayat itu mengindikasikan suatu keadaan di mana ada orang yang sudah bisa menyaksikan hilal dan ada yang belum bisa karena berbeda tempatnya atau berbeda mathla'nya. Orang yang sudah bisa menyaksikan berarti ia sudah wajib berpuasa, tetapi orang yang belum bisa menyaksikan, ia belum terkena kewajiban itu. Karena perbedaan mathla' itu bisa terjadi dalam satu wilayah suatu Negara, demi kemaslahatan dalam penyelenggaraan administrasi Negara, maka dikembangkanlah konsep mathla' wilayatul hukmi. Artinya, jika mayoritas wilayah suatu negara telah menyaksikan awal bulan qamariyah, maka seluruh wilayah negara itu dianggap telah menyaksikannya.

\section{Bibliografi}

An-Nawawi, Al-Imam. Al-Majmu' Syarh al-Muhazdzdab. Madinah: Al-Maktabah al-Salafiyah, n.d.

Azhari, Susiknan. Hisab Dan Rukyah Wacana Untuk Membangun Kebersamaan Di Tengah Perbedaan. Yogyakarta: Pustaka Pelajar, 2007.

Bukhari, Muhammad ibn Isma'il ibn Ibrahim ibn al-Mugirah al-. Shabih AlBukhari. Riyadh: Maktabah al-Ma'arif, 1997.

Cordoba, Tim. Al-Qur'anul Karim, Tafsir Tematik. Ayat-Ayat Piliban, Terjemahan PerKata, Dan Tajwid Metode Warna. Bandung: Cordoba, 2016.

Jauziyyah, Ibn al-Qayyim al-. I'lam al-Muwaqqi'in 'an Rabbal-'Alamin. Beirut: Dar al-Jil, 1973.

Jaziri, Abd Ar-Rahman al-. Kitab Fiqh 'Ala Mazabibil Arba'Ah. Beirut: Dar alMaktab al-'Ilmiyah, n.d. 
180 | AL QUDS : Jurnal Studi Alquran dan Hadis vol. 4, no 1, 2020

Khalaf, Abdul Wahab. Tlmu Usul al-Fiqh. Kairo: Maktabah al-Da'wah alIslamiyyah, 1972.

Murtadho, Moh. Ilmu Falak Praktis. Malang: UIN-Malang Press, 2008.

Naisaburi, Muslim bin al-Hajjaj al-. Sabih Muslim. Beirut: Dar Ihya al-Turats Arabi, n.d.

Qardhawi, Yusuf. Pengantar Studi Hadits. Bandung: CV. Pustaka Setia, 2007.

Ruskanda, S. Farid. 100 Masalab Hisab dan Rukyat: Telaah Syariah, Sains dan Teknologi. Jakarta: Gema Insani, 1996. 